\title{
TINJAUAN PUSTAKA KARAKTERISASI DAN POTENSI PEMANFAATAN FLY ASH DAN BOTTOM ASH (FABA)
}

\section{REVIEW ON CHARACTERIZATION AND UTILIZATION POTENTIAL OF FLY ASH AND BOTTOM ASH (FABA)}

\author{
Ferian Anggara ${ }^{1,2}$, Himawan T.B.M. Petrus ${ }^{2,3^{*}}$, Dea Anisa Ayu Besari ${ }^{1}$, \\ Hotden Manurung ${ }^{3}$, dan Febry Yulindra Abdi Saputra ${ }^{2}$ \\ ${ }^{1}$ Departemen Teknik Geologi, Fakultas Teknik, Universitas Gadjah Mada \\ ${ }^{2}$ Pusat Kajian Sumberdaya Bumi Non-Konvensional, Fakultas Teknik, \\ Universitas Gadjah Mada \\ ${ }^{3}$ Departemen Teknik Kimia, Fakultas Teknik, Universitas Gadjah Mada \\ "bayupetrus@ugm.ac.id
}

\begin{abstract}
ABSTRAK
Fly ash dan bottom ash (FABA) merupakan limbah hasil sisa pembakaran batubara dari pembangkit listrik tenaga uap (PLTU). FABA yang dihasilkan akan terus meningkat seiring dengan meningkatnya kebutuhan energi listrik yang harus dipenuhi. Komposisi FABA secara umum berupa silika, alumina, oksida besi, dan senyawa oksida lainnya. Abu yang dihasilkan dari pembakaran batubara berpotensi secara ekonomis karena mengandung beberapa unsur berharga antara lain $\mathrm{Ge}, \mathrm{Ga}$, unsur tanah jarang (REY), $\mathrm{Nb}, \mathrm{Zr}, \mathrm{V}, \mathrm{Re}, \mathrm{Au}, \mathrm{Ag}$, dan logam dasar seperti Al. Karakteristik fisik dan kimia FABA merupakan aspek penting yang dapat memengaruhi, baik potensi penggunaan maupun metode pembuangan atau penyimpanan limbah yang akan dilakukan. Potensi pemanfaatan FABA telah banyak digunakan pada bidang geoteknik, salah satunya diaplikasikan sebagai material geopolimer. Selain itu, FABA juga mengandung cenosphere yang merupakan salah satu material bernilai ekonomis tinggi dan telah banyak diaplikasikan pada berbagai bidang industri. Berbagai teknik pemisahan material untuk meningkatkan potensi nilai guna FABA telah berhasil dikembangkan, antara lain metode ektraksi cenosphere, logam berharga serta unsur jejak seperti REY, juga unburned carbon.
\end{abstract}

Kata kunci: FABA, komposisi, pemanfaatan, REY, cenosphere, geopolimer

\section{ABSTRACT}

Fly ash and bottom ash (FABA) is defined as waste residu that is produced from coal combustion process in electric power plant. Its production will increase due to high demand of electric energy. It commonly consists of silica, alumina, ferric oxide, and others oxide. Coal ash is also an economically promising resource for extraction of several valuable elements, including $\mathrm{Ge}, \mathrm{Ga}$, rare earth elements and yttrium (REY), Nb, Zr, V, Re, Au, Ag, and base metals such as Al. Physical and chemical characteristics of FABA are important because it will affect their option of re-use and disposal method. Other potential utilization for FABA was involved geotechnical applications such as geopolymer material. Cenospheres are one of the most valuable materials found in FABA. To increase the potential use of FABA, many separation techniques have been developed to extract the value-added components, including: cenospheres, valuable metal and trace elements such as rare earth element and yttrium (REY), also the unburned carbon.

Keywords: FABA, composition, utilization, REY, cenosphere, geopolymer 


\section{PENDAHULUAN}

Pembakaran batubara tidak hanya menghasilkan energi listrik namun juga menghasilkan limbah abu sisa pembakaran berupa fly ash dan bottom ash (FABA). Jumlah konsumsi batubara untuk kelistrikan dan bidang manufaktur pada tahun 2019 telah mencapai 138,42 juta ton (Direktorat Jenderal Mineral dan Batubara, 2019), dengan estimasi limbah FABA yang dihasilkan diperkirakan akan mencapai $5 \%$ dari jumlah total batubara yang dibakar sehingga pada tahun 2019 diperkirakan mencapai 6,92 juta ton.

Berdasarkan pada Peraturan Pemerintah No. 22 Tahun 2021 tentang penyelenggaraan perlindungan dan pengelolaan lingkungan hidup, FABA yang dihasilkan dari proses pembakaran batubara pada PLTU digolongkan sebagai limbah non-bahan berbahaya dan beracun (non-B3). Namun, pemanfaatan limbah FABA di dunia secara umum baru mencapai $25 \%$ dari jumlah total abu batubara yang dihasilkan dan $75 \%$ sisanya terbuang percuma sebagai limbah dan polusi (Sommerville et al., 2013; Blissett and Rowson, 2012).

Karakterisasi sifat fisik dan komposisi penyusun FABA secara komprehensif telah banyak dilakukan di berbagai negara antara lain Bulgaria, Belanda, Italia, Turki, Yunani (Vassilev and Vassileva, 2007); Amerika Serikat (Kutchko and Kim, 2006), Kanada (Goodarzi, 2006), dan Australia (Ngu et al., 2007). Sementara itu karakterisasi komponen penyusun FABA yang telah dilakukan di Indonesia masih terbatas pada FABA yang dihasilkan oleh PLTU di Pulau Jawa (Besari, 2018).

Karakterisasi FABA menjadi penting untuk dilakukan karena berkaitan dengan sistem daur ulang dan potensi pemanfaatan untuk jenis komponen penyusun FABA yang berbeda (Ranjbar and Kuenzel, 2017; Yao et al., 2015).

Pada artikel ini akan diulas karakterisasi FABA, potensi, dan pemanfaatannya.

\section{METODOLOGI}

Artikel ini merupakan hasil tinjauan literatur yang memberikan gambaran karakter FABA dari pembakaran batubara di PLTU. Karakterisasi FABA dilakukan untuk mengetahui sifat-sifat: fisik, kimiawi, dan geoteknik (Bhatt et al., 2019; Reddy et al., 2018). Karakterisasi FABA juga dapat menentukan pemanfaatan FABA tersebut. Berat jenis merupakan sifat fisik yang sangat penting untuk dianalisis, terkait dengan penggunaan FABA pada bidang geoteknik (Reddy et al., 2018). Uji berat jenis digunakan untuk mengetahui nilai berat jenis $F A B A$ yang umumnya berkisar 1,6-3,1 (Bhatt et al., 2019).

Sifat kimiawi FABA dapat dianalisis menggunakan analisis $X$-Ray Diffraction (XRD) dan Scanning Electron MicrosopeEnergy Dispersive X-Ray (SEM-EDX) (Reddy et al., 2018). Metode yang digunakan untuk mengetahui karakteristik geoteknik FABA meliputi analisis distribusi ukuran butir, nilai Atterberg limits, kadar air maksimum, densitas kering maksimum, permeabilitas, konduktivitas hidrolik, dan sudut dari friksi internal $\Phi$ (Bhatt et al., 2019).

\section{KARAKTERISASI KOMPOSISI FABA}

Metode pembakaran batubara yang paling umum, terutama untuk produksi energi dalam skala besar, adalah pembakaran bahan bakar bubuk (pulverized coal), juga disebut sebagai pembakaran fase-terfokus atau pembakaran dengan suspensi. Pada proses ini batubara ditumbuk menjadi bubuk halus dan diinjeksikan dengan aliran udara ke ruang tungku, sehingga menyala membentuk bola api pada kisaran suhu antara $1300^{\circ} \mathrm{C}-1700^{\circ} \mathrm{C}$. Sebagian besar abu yang dihasilkan dari proses ini bergerak sebagai partikel tersuspensi bersama dengan gas pembakaran, kemudian ditangkap oleh electrostatic precipitators (ESPs) atau peralatan filtrasi partikel lainnya seperti bag house filter, dengan abu tersebut dikenal sebagai Fly Ash (FA), sedangkan bottom ash (BA) adalah abu yang bercampur dengan fragmen hasil 
pembakaran lainnya, terlepas dari endapan yang terbentuk pada dinding tungku pembakaran dan kemudian jatuh ke bagian bawah ruang pembakaran (Hower et al., 2017a). FA tersusun oleh material yang bersifat heterogen yang umumnya berbentuk bulat dengan ukuran berkisar antara $0,5 \mu \mathrm{m}-300 \mu \mathrm{m}$ sedangkan BA memiliki ukuran yang lebih kasar $>0,5 \mu \mathrm{m}$ (Chiang and Pan, 2017). Komposisi kimia FABA sangat bervariasi tergantung pada komposisi dan ukuran partikel batubara asal.

FA tersusun oleh partikel-partikel serbuk halus yang sebagian besar berbentuk bola, baik padat atau berlubang, dan sebagian besar bersifat amorf. Secara umum, abu batubara memiliki nilai berat jenis sekitar 2,0 namun dapat bervariasi sebagian besar berkisar mulai dari 1,6 s.d. 3,1 . Variasi ini disebabkan oleh kombinasi beberapa faktor seperti bentuk partikel, gradasi, dan komposisi kimia (Pandian, 2013). Berdasarkan distribusi ukuran butirnya, FA tersusun oleh partikel berukuran butir pasir hingga lanau. FA memiliki luas permukaan yang tinggi dengan nilai bulk density yang rendah (Ram et al., 2014). Jumlah karbon yang tidak habis terbakar (unburned carbon / UC) dan senyawa besi yang tidak terbakar memengaruhi warna FA yang dihasilkan, sehingga dapat bervariasi dari oranye hingga merah tua, cokelat, atau putih hingga kuning (Ahmaruzzaman, 2010).

FA merupakan salah satu material dengan karakteristik yang paling kompleks karena dapat tersusun oleh komposisi mineral yang sangat bervariasi, 188 kelompok mineral yang terdiri dari 316 individu mineral ditemukan menjadi penyusun FA (Vassilev and Vassileva, 2007). Senyawa utama penyusun coal fly ash (CFA) adalah $\mathrm{SiO}_{2}$, $\mathrm{Al}_{2} \mathrm{O}_{3}$, dan $\mathrm{Fe}_{2} \mathrm{O}_{3}$, dengan jumlah karbon yang bervariasi (direpresentasikan sebagai loss on ignition (LOI)), $\mathrm{CaO}$, dan $\mathrm{MgO}$ (Sahoo et al., 2016). FA dapat diklasifikasikan berdasarkan peringkat batubara asalnya meliputi FA bituminus, sub-bituminus, dan lignit (Meawad et al., 2010). FA dari pembakaran lignit dan batubara sub-bituminus dicirikan oleh konsentrasi kalsium dan magnesium oksida yang lebih tinggi dan berkurangnya persentase silika dan besi oksida, serta kandungan karbon yang lebih rendah, dibandingkan dengan FA batubara bituminus.

Sifat fisik dan kimia FA tidak hanya bergantung pada jenis batubara yang digunakan dalam proses pembakaran, namun juga pada teknik yang digunakan untuk membakar batubara. Sifat FA yang dihasilkan dipengaruhi oleh: (i) konfigurasi boiler, (ii) kondisi pembakaran dan suhu boiler, (iii) ukuran partikel batubara, dan (iv) peralatan gas cleaning (Mukherjee et al., 2008).

Rangkuman variasi komposisi kimia FA di seluruh dunia memperlihatkan kelimpahan $\mathrm{SiO}_{2}$ pada $\mathrm{FA}$ di India (50-60\%) jauh lebih tinggi jika dibandingkan FA di Cina dan Amerika Serikat (AS) (36-38\% hingga 57$58 \%$ ). FA dari Yunani memiliki kelimpahan $\mathrm{SiO}_{2}$ terendah khususnya untuk FA dari batubara peringkat lignit, yang secara umum memiliki kandungan $\mathrm{SiO}_{2}$ rendah (Tabel 1). Kelimpahan $\mathrm{Al}_{2} \mathrm{O}_{3}$ relatif bervariasi untuk FA dari Cina dibandingkan dengan FA dari negara-negara lain yang terdaftar. Sedangkan kelimpahan $\mathrm{Al}_{2} \mathrm{O}_{3}$ untuk FA dari Belanda, Yunani, dan Afrika Selatan, tidak terlalu bervariasi. Kelimpahan $\mathrm{CaO}$ bervariasi, umumnya di atas $15 \%$ untuk FA dari AS, Jerman, Polandia, Yunani, dan Eropa yang secara keseluruhan FA menunjukkan sifat selfcementing.

Uji LOI (loss of ignition) digunakan untuk mengidentifikasi UC dan oksida logam pada FA (Bhatt et al., 2019). Nilai LOI bervariasi seiring dengan perubahan kondisi proses pembakaran. Kisaran nilai LOI pada FA batubara di Eropa bervariasi umumnya berkisar $30 \%$. Hal ini mengindikasikan banyaknya karbon yang tidak terbakar sehingga dapat mengurangi kegunaan abu terbang (Bhatt et al., 2019).

Studi petrografi yang dilakukan oleh Hower (2012) menunjukkan bahwa FA tersusun oleh komponen anorganik dan organik dari 
sisa pembakaran batubara, dan material baru (neoformed) yang terbentuk pada boiler dan flue gas stream (Tabel 2). Hower et al., (2017a) telah mengklasifikasikan komponen FA berdasarkan tekstur dan genetiknya (Tabel 3).

Tabel 1. Rangkuman variasi komposisi kimia FA dari berbagai negara di dunia

\begin{tabular}{|c|c|c|c|c|c|c|c|c|c|c|c|c|}
\hline \multirow{2}{*}{ Negara } & \multicolumn{12}{|c|}{ \% Komposisi Kimia } \\
\hline & $\mathrm{SiO2}$ & Al2O3 & $\mathrm{Fe} 2 \mathrm{O} 3$ & $\mathrm{CaO}$ & K2O & MgO & SO3 & TiO2 & $\mathrm{Na2O}$ & P205 & $\mathrm{MnO}$ & LOI \\
\hline Australia & $31,1-68,6$ & $17-33$ & $1-27,1$ & $0,1-5,3$ & $0,1-2,9$ & $0-2$ & $0-0,6$ & $1,2-3,7$ & $0-1,5$ & $0-3,9$ & nd & na \\
\hline Banglades & 55 & 24,7 & 7,7 & 6,2 & 1,1 & 0,7 & 1,1 & na & na & 0,9 & 0,1 & na \\
\hline Bulgaria & $30,1-57,4$ & $12,5-25,4$ & $5,1-21,2$ & $1,5-28,9$ & $0,8-2,8$ & $1,1-2,9$ & $0,4-12,7$ & $0,6-1$ & $0,4-1,9$ & $0,1-0,4$ & $0-0,2$ & $0,8-32,8$ \\
\hline Kanada & $35,5-62,1$ & $12,5-23,2$ & $3-44,7$ & $1,2-13,3$ & $0,5-3,2$ & $0,4-3,1$ & $0,2-7,8$ & $0,4-1$ & $0,1-7,3$ & $0,1-1,5$ & na & $0,3-9,7$ \\
\hline Cina & $35,6-57,2$ & $18,8-55$ & 2,3-19,3 & $1,1-7$ & $0,8-0,9$ & $0,7-4,8$ & $1-2,9$ & $0,2-0,7$ & $0,6-1,3$ & $1,1-1,5$ & nd & nd \\
\hline Denmark & $48-65$ & $26-33$ & $3,3-8,3$ & $2,2-7,8$ & na & na & na & na & $1,1-2,8$ & na & na & $3,1-4,9$ \\
\hline Eropa & $28,5-59,7$ & $12,5-35,6$ & $2,6-21,2$ & $0,5-28,9$ & $0,4-4$ & $0,6-3,8$ & $0,1-12,7$ & $0,5-2,6$ & $0,1-1,9$ & $0,1-1,7$ & $0-0,2$ & $0,8-32,8$ \\
\hline Perancis & $47-51$ & $26-34$ & $6,9-8,8$ & $2,3-3,3$ & na & $1,5-2,2$ & $0,1-0,6$ & na & $2,3-6,4$ & na & na & $0,5-4,5$ \\
\hline Jerman & $20-80$ & $1,0-19$ & $1,0-22$ & $2,0-52$ & $0-2$ & $0,5-11$ & $1,0-15$ & $0,1-1$ & $0-2$ & na & na & $0-5$ \\
\hline Yunani & $21-35$ & $10-17,9$ & $4,5-8,4$ & $27,3-45$ & $0,4-1$ & $1,5-3,8$ & $4-8,6$ & na & $0,2-1$ & na & na & $3,0-7,0$ \\
\hline India & $50,2-59,7$ & $14-32,4$ & $2,7-16,6$ & $0,6-9$ & $0,2-4,7$ & $0,1-2,3$ & na & $0,3-2,7$ & $0,2-1,2$ & na & na & $0,5-7,2$ \\
\hline Israel & $45,6-58,6$ & $24,4-34,5$ & $3-6,7$ & $4,9-9,9$ & 0,1 & $1,6-2,5$ & $0,6-0,8$ & $1,2-1,9$ & $0-0,1$ & $0,8-1,8$ & na & 6 \\
\hline Italia & $41,7-54$ & $25,9-33,4$ & $3-8,8$ & $2,0-10$ & $0-2,6$ & $0-2,4$ & na & $1-2,6$ & $0-1$ & $0-1,5$ & $0-0,1$ & $1,9-9$ \\
\hline Jepang & $53,9-63$ & $18,2-26,4$ & $4,2-5,7$ & $2-8,1$ & $0,6-2,7$ & $0,9-2,4$ & $0,3-1,4$ & $0,8-1,2$ & $1,1-2,1$ & na & na & $0,5-2,1$ \\
\hline Korea & $50-55,7$ & $24,7-28,7$ & $3,7-7,7$ & $2,6-6,2$ & 1,1 & $0,7-1,1$ & $0,5-1,1$ & na & na & 0,9 & 0,1 & $4,3-4,7$ \\
\hline Meksiko & 59,6 & 22,8 & 5,6 & 3,1 & 1,3 & 0,9 & 0,4 & 0,9 & 0,5 & 0 & na & na \\
\hline Belanda & $45,1-59,7$ & $24,8-28,9$ & $3,3-9$ & $0,5-6,8$ & $0,6-2,9$ & $0,6-3,7$ & $0,2-1,3$ & $0,9-1,8$ & $0,1-1,2$ & $0,1-1,5$ & $0-0,1$ & $2,7-8,1$ \\
\hline Cina Utara & 43,7 & 44 & 3,5 & 0,9 & 0,9 & 0,4 & 0,7 & 1,5 & 0,3 & na & na & 10 \\
\hline Polandia & $32,2-53,3$ & $4-32,2$ & $4,5-8,9$ & $1,2-29,9$ & $0,2-3,3$ & $1,2-5,9$ & na & $0,6-2,2$ & $0,2-1,5$ & $0,1-0,9$ & $0-0,3$ & $0,5-28$ \\
\hline Rusia & $40,5-48,6$ & $23,2-25,9$ & na & $6,9-13,2$ & $1,9-2,6$ & $2,6-4$ & na & $0,5-0,6$ & $1,2-1,5$ & $0,3-0,4$ & $0,2-0,4$ & na \\
\hline Afrika Selatan & $46,3-67$ & $21,3-27$ & $2,4-4,7$ & $6,4-9,8$ & $0,5-1$ & $1,9-2,7$ & na & $1,2-1,6$ & $0-1,3$ & $0,3-0,9$ & $0-0,5$ & na \\
\hline Spanyol & $41,5-58,6$ & $17,6-45,4$ & $2,6-16,2$ & $0,3-11,8$ & $0,2-4$ & $0,3-3,2$ & $0,1-2,2$ & $0,5-1,8$ & $0-1,1$ & $0,1-1,7$ & $0-0,1$ & $1,1-9,7$ \\
\hline Spanyol & $41,5-58,6$ & $17,6-35,6$ & $2,6-16$ & $0,8-11,8$ & $0,4-4$ & $0,9-2,5$ & $0,1-2,2$ & $0,5-1,6$ & $0,2-0,8$ & $0,1-1,7$ & $0-0,1$ & $1,1-5,2$ \\
\hline Turki & $37,9-57$ & $20,5-24,3$ & $4,1-10,6$ & $0,2-27,9$ & $0,4-3,5$ & $1-3,2$ & $0,6-4,8$ & $0,6-1,5$ & $0,1-0,6$ & $0,2-0,3$ & 0 & $0,4-2,7$ \\
\hline Amerika Serikat & $34,9-58,5$ & $19,1-28,6$ & $3,2-25,5$ & $0,7-22,4$ & $0,9-2,9$ & $0,5-4,8$ & $0,1-2,1$ & $1-1,6$ & $0,2-1,8$ & $0,1-1,3$ & na & $0,2-20,5$ \\
\hline Minimum & 20.0 & 1.0 & 1.0 & 0,1 & 0.0 & 0.0 & 0.0 & 0,1 & 0.0 & 0.0 & 0.0 & 0.0 \\
\hline Maksimum & 80.0 & 55.0 & 44,7 & 52.0 & 4,7 & 11.0 & 15.0 & 3,7 & 7,3 & 3,9 & 0,5 & 32,8 \\
\hline
\end{tabular}

Keterangan: $\mathrm{nd}=$ tidak terdeteksi, $\mathrm{na}=$ tidak dianalisis

Sumber: (Bhatt et al., 2019)

Tabel 2. Komponen Penyusun FA

\begin{tabular}{|c|c|}
\hline Anorganik & Organik \\
\hline $\begin{array}{cl}\text { Material } & \text { Baru (Neoformed): } \\
- & \text { Glass } \\
- & \text { Mulit } \\
- & \text { Spinel } \\
- & \text { Kapur } \\
- & \text { Sulfat } \\
- & \text { Mineral yang teroksidasi }\end{array}$ & $\begin{array}{cl}\text { Material Baru (Neoformed): } \\
-\quad \text { Arang atau kokas isotropik } \\
-\quad \text { Arang atau kokas anisotropik }\end{array}$ \\
\hline 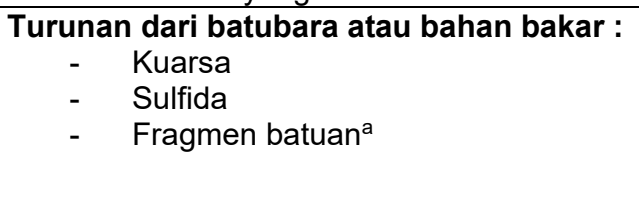 & 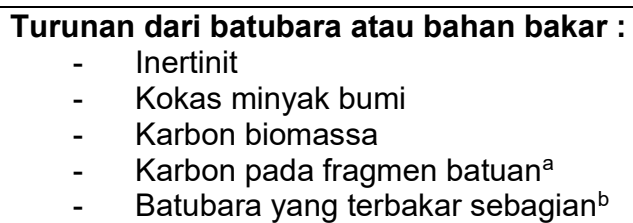 \\
\hline
\end{tabular}

${ }^{a} F r a g m e n$ batuan umumnya memiliki permukaan gelasan, mengelilingi mineral yang terbakar dan (terkadang) karbon ${ }^{b}$ Fragmen batubara yang terbakar sebagian dapat memiliki kenampakan yang menunjukkan berbagai tingkat devolatilisasi

Sumber: (Hower, 2012) 
Tabel 3. Klasifikasi genetik dan tekstural komponen penyusun FA

\begin{tabular}{|c|c|}
\hline \multicolumn{2}{|c|}{ Komponen Penyusun Fly Ash (FA) } \\
\hline Klasifikasi Genetik & $\begin{array}{c}\text { Klasifikasi Tekstural } \\
\text { (untuk karbon/arang isotropik dan anisotropik, } \\
\text { dan inertinit) }\end{array}$ \\
\hline $\begin{array}{ll}- & \text { Karbon/arang isotropik (dari vitrinit atau inertinit) } \\
- & \text { Karbon/arang anisotropik (dari vitrinit atau inertinit) } \\
- & \text { Inertinit } \\
- & \text { Glass } \\
- & \text { Mulit } \\
- & \text { Spinel } \\
- & \text { Kuarsa } \\
- & \text { Sulfida } \\
- & \text { Sulfat } \\
- & \text { Batubara yang tidak terbakar } \\
- & \text { Material organik non-batubara } \\
- & \text { Mineral lain/ material anorganik non-batubara }\end{array}$ & $\begin{array}{ll}\text { - } & \text { Tenuisphere } \\
\text { - } & \text { Crassispere } \\
\text { - } & \text { Tenuinetwork } \\
\text { - } & \text { Crassinetwork } \\
\text { - } & \text { Inertoid } \\
\text { - } & \text { Fusinoid } \\
\text { - } & \text { Solid } \\
\text { - } & \text { Mineroid } \\
\text { - } & \text { Campuran material berpori } \\
\text { - } & \text { Campuran material padatan }\end{array}$ \\
\hline
\end{tabular}

Sumber: (Hower et al., 2017a)

Keterdapatan UC pada FA mengindikasikan inefisiensi proses pembakaran batubara (Hower et al., 2017b). Proporsi UC dalam jumlah yang melimpah mengindikasikan bahwa banyak energi yang hilang ketika proses pembakaran batubara berlangsung. Pembentukan UC dipengaruhi oleh berbagai kombinasi faktor yang meliputi peringkat dan komposisi maseral batubara, penggilingan batubara umpan yang buruk, penggunaan batubara umpan yang tidak cocok untuk boiler, serta kondisi pembakaran (Hower et al., 2017b).

Terminologi "unburned coal" jarang digunakan, namun pada sebagian besar kasus, hal tersebut tidak dapat merepresentasikan sifat asli karbon yang ada pada FA (Hower et al., 2017b). Batubara peringkat bituminus dengan kategori caking coal mengalami pelelehan dengan cepat dan terdevolatilisasi di boiler. Beberapa maseral vitrinit meleleh, terdevolatilisasi, dan pada akhirnya melewati boiler ke sistem pengumpulan abu. Bentuk asli maseral tersebut secara samar masih dapat dikenali pada beberapa FA (Gambar 1). Karbon pada FA telah mengalami devolatilisasi dan bukan merupakan batubara karena secara kimiawi tidak merepresentasikan partikel batubara aslinya (Hower et al., 2017b). Karbon hasil pembakaran batubara peringkat lignit dan sub-bituminus yang tidak termasuk caking coal akan membentuk char (Gambar 1(b)).
Maseral inertinit umumnya melewati boiler dalam keadaan yang relatif utuh meskipun terdapat indikasi mengalami devolatilisasi dan pembakaran (Gambar 1 (c)). Komposisi FABA secara umum dominan tersusun oleh komponen anorganik meliputi fragmen batuan, kuarsa, mineral pembawa unsur Fe, mineral silikat suhu tinggi, glass dan mineral pengikut, serta komponen non-bahan bakar (Hower et al., 2017b). Variasi kelompok mineral yang umum ditemukan pada FA dapat dilihat pada Tabel 4.

\section{(a). Fragmen Batuan dan Kuarsa}

Fragmen batuan yang tervitrifikasi terbentuk karena proses pembakaran batubara yang tidak sempurna (Gambar 2). Pada beberapa kasus, coked carbons terlihat pada bagian dalam partikel fragmen batuan, yang menunjukkan bahwa pemanasan cukup untuk medevolatilisasi material organik, tetapi tidak mampu melakukan vitrifikasi secara menyeluruh pada seluruh butiran. Kuarsa merupakan mineral yang paling umum ditemukan pada abu batubara. Kuarsa pada abu batubara dapat berupa kuarsa primer maupun sekunder (a). Fragmen batuan; (b). Kuarsa. (Hower et al., 2017b)). Kuarsa pada umumnya tidak meleleh ketika suhu pembakaran pada boiler mencapai $1400-1500^{\circ} \mathrm{C}$ sehingga dapat ditemukan pada FA dalam bentuk kristalin sebagai kuarsa primer (Hower, 2012). 


\section{MAKALAH ILMIAH}
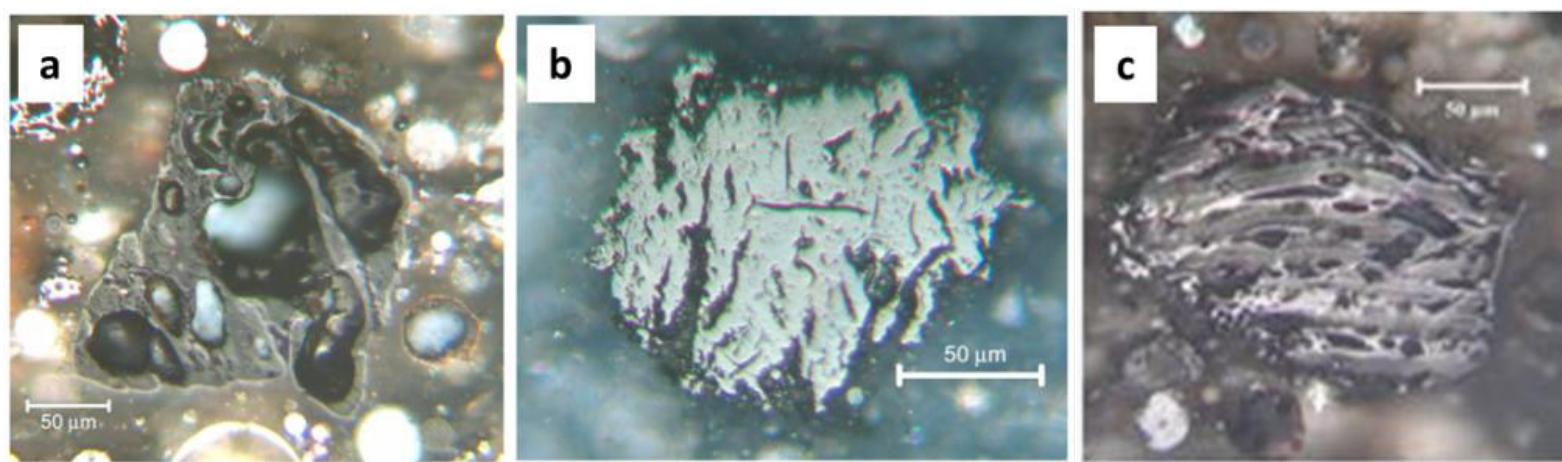

Gambar 1. (a). Unburned coal; (b). Char; (c). Karbon turunan maseral inertinit Sumber: (Hower et al., 2017b)

Tabel 4. Skema perubahan mineral pada batubara selama proses pembakaran

\begin{tabular}{c|l}
\hline \multicolumn{1}{c}{ Komponen Mineral } & \multicolumn{1}{c}{ Pembakaran } \\
\hline $\mathrm{Ca}, \mathrm{Na}$, dll (pada karboksilat) & $\begin{array}{l}\text { Kebanyakan menjadi sulfat; dapat pula berekasi } \\
\text { dengan } \mathrm{SiO}_{2} \text {, dll, untuk membentuk silikat }\end{array}$ \\
\hline Pirit & $\begin{array}{l}\text { Teroksidasi menjadi hematit }\left(\mathrm{Fe}_{2} \mathrm{O}_{3}\right) \text { atau } \\
\text { magnetit }\left(\mathrm{Fe}_{3} \mathrm{O}_{4}\right) \text {; bereaksi dengan silikat }\end{array}$ \\
\hline Karbonat & $\begin{array}{l}\text { Terdisosiasi menjadi oksida; bereaksi dengan } \\
\text { silikat }\end{array}$ \\
\hline Mineral Lempung & $\begin{array}{l}\text { Dehidrasi dan sintering; kemungkinan menjadi } \\
\text { mulit; reaksi produk dengan } \mathrm{Fe}_{2} \mathrm{O}_{3} \text { dari pirit, CaO } \\
\text { dari karbonat, dan SiO } \mathrm{S}_{2} \text {, dll }\end{array}$ \\
\hline Kuarsa & $\begin{array}{l}\text { Relict; bereaksi dengan aluminasilikat dari } \\
\text { mineral lempung, dengan CaO dan } \mathrm{Fe}_{2} \mathrm{O}_{3} \text { untuk } \\
\text { membentuk fase silikat kristal dan cair }\end{array}$ \\
\hline
\end{tabular}

Sumber: (Mraw et al., 1983)

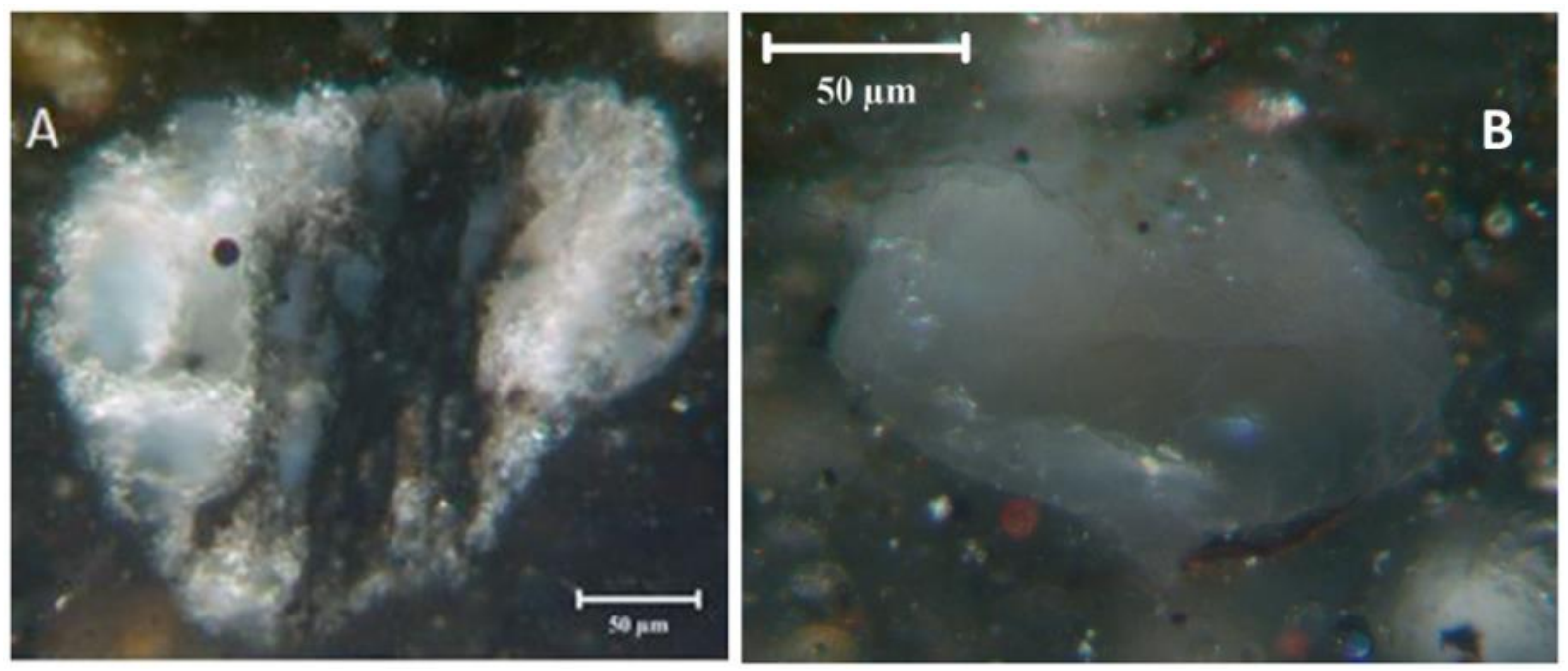

Gambar 2. (a).Fragmen batuan; (b). Kuarsa

Sumber: (Hower et al., 2017b)

(b). Mineral Pembawa Unsur Fe

Mineral pembawa unsur Fe dapat bereaksi untuk membentuk senyawa oksida besi yang terpisah, namun Fe dalam bentuk lain (misalnya bahan anorganik nonmineral) dapat berinteraksi dengan residu aluminosilikat dan berpotensi mengakibatkan slagging (Gambar 3). 
Dekomposisi pirit dalam api pembakaran berlangsung cepat: 400 ms untuk pirit 53-63 $\mu \mathrm{m}$ dan $575 \mathrm{~ms}$ untuk pirit 75-90 $\mu \mathrm{M}$, dimana transformasi awal dari pirit (Py) adalah ke pirotit (Po) (Srinivasachar et al., 1990). Pada suhu pembakaran $1500^{\circ} \mathrm{K}$ dan $\mathrm{S} /(\mathrm{S}-\mathrm{Fe})$ bernilai $<0,1$ atau $1400^{\circ} \mathrm{K}$ dan nilai $\mathrm{S} /(\mathrm{S}-\mathrm{Fe}) \quad<0,17$, magnetit mengalami kristalisasi dari lelehan. Konversi magnetit menjadi hematit terjadi secara lambat dan terbatas secara kinetik, membutuhkan lebih banyak waktu pada zona panas di dalam furnace. Hematit terbentuk dari proses dekomposisi mineral sulfida besi pada kondisi oksidasi. Hematit umumnya stabil pada suhu di bawah $1400^{\circ} \mathrm{C}$. Berbeda dengan butiran pirit bebas, pirit dalam clay bands cenderung menyatu dengan mineral lempung dan silika untuk membentuk glass Fe-K-Al-Si (Abbott and Austin, 1985; Srinivasachar et al., 1990).

Dalam nomenklatur petrografi istilah "spinel" digunakan sebagai kategori mineral yang luas, termasuk magnetit. Banyak mineral dalam keluarga spinel memiliki struktur cacat dan mencakup sejumlah elemen seperti $\mathrm{Al}, \mathrm{Mg}, \mathrm{Ni}, \mathrm{Cr}$, dan lainnya. Besi dalam mineral sekunder berasal dari dekomposisi Fe-sulfida dan mineral-mineral lain yang mengandung Fe dalam batubara. Mineral spinel dapat membentuk baik struktur dendritik halus maupun kasar dalam matriks glass (Gambar 3(b)).

\section{(c). Mineral Silikat Suhu Tinggi}

Mulit, anortit, dan mineral Al-Si lainnya dapat dapat terbentuk melalui reaksi pada kondisi padat atau dapat mengkristal dari lelehan (Gambar 4). Fase mineral tergantung pada suhu yang dicapai dan kecepatan pendinginan, maupun komposisi kimia bahan serta potensi interaksi antara fase yang terlibat. Komponen BA cenderung mendingin lebih lambat dibanding FA. Pada sistem $\mathrm{CaO}-\mathrm{Al}_{2} \mathrm{O}_{3}-\mathrm{SiO}_{2}$, kristalisasi mulit terjadi pada rentang suhu $1200-1300^{\circ} \mathrm{C}$.

(d). Glass dan Mineral Pengikut

Glass aluminosilikat amorf merupakan komponen yang umum ditemukan pada FABA (Gambar 5) yang terbentuk pada suhu di atas $1000^{\circ} \mathrm{C}$. Glass berdasarkan morfologinya dapat dibedakan menjadi cenospheres (berbentuk bulat) dan pleiospheres (tidak berbentuk bulat sempurna). Material amorf (glass) kurang melimpah (57\%-82\%) pada abu yang dihasilkan dari sistem pembakaran FBC jika dibandingkan dengan pembakaran menggunakan sistem pulverized-coal yang menghasilkan glass mencapai $80 \%-97 \%$. Hal tersebut terjadi disebabkan suhu operasional pada sistem FBC lebih rendah.
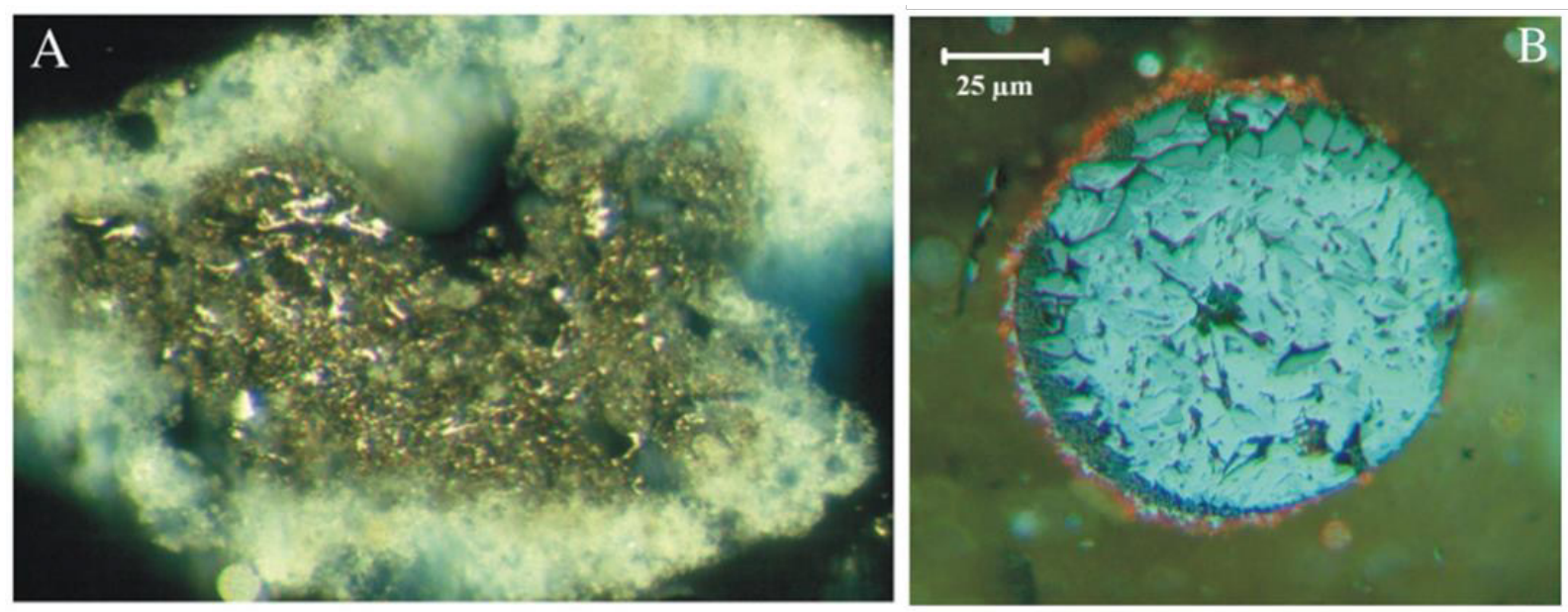

Gambar 3. (a).Fragmen batuan dengan glassy rim; (b). Dendritik spinel

Sumber: (Hower et al., 2012) 


\section{MAKALAH ILMIAH}
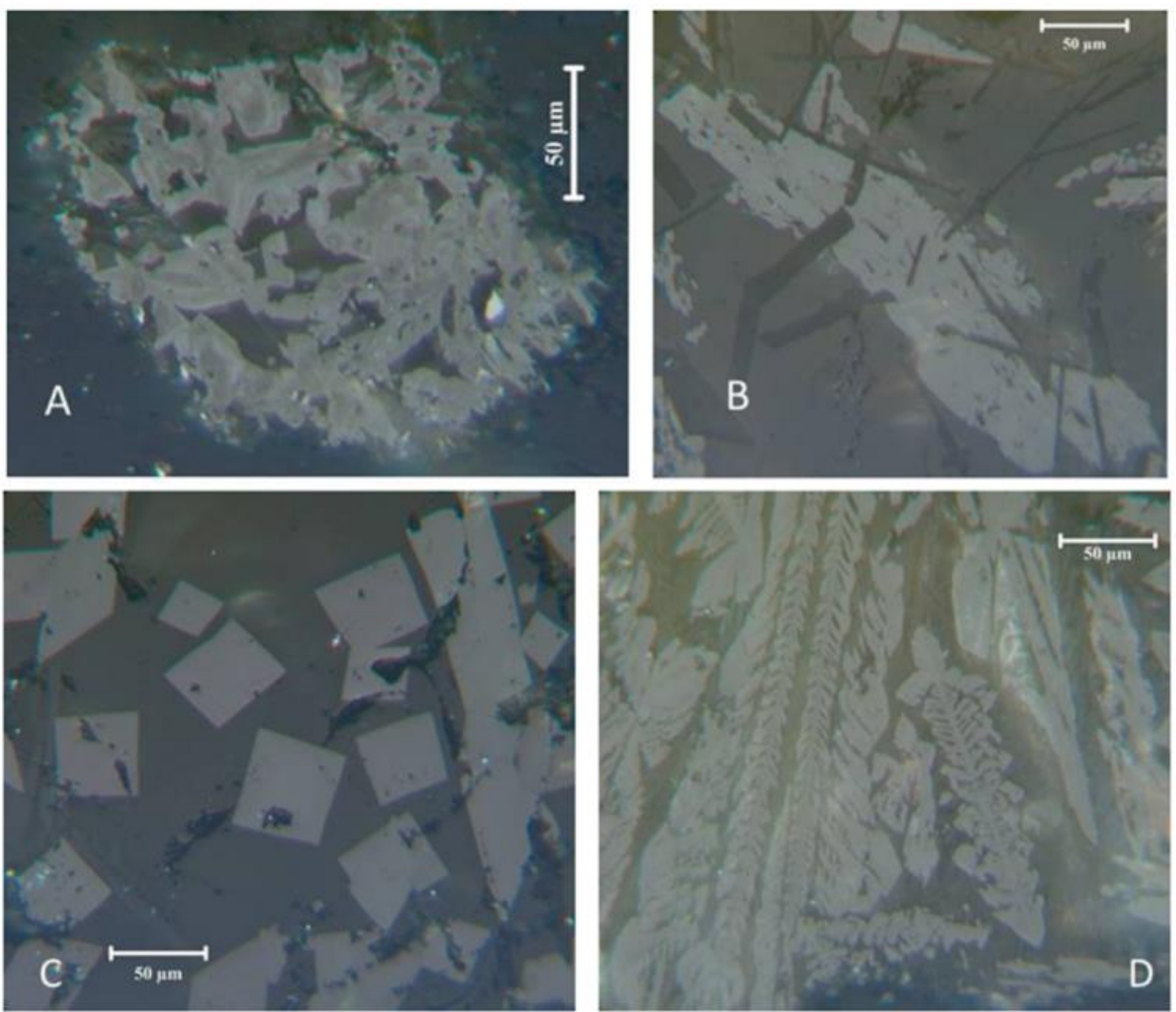

Gambar 4. Mulit dan neoformed minerals

Sumber: (Hower et al., 2017b)

(e). Komponen Non-bahan Bakar

Material asing non-bahan bakar dapat dapat ditemukan pada FABA (Gambar 6) menunjukkan sepotong logam dengan struktur pelarutan yang bukan terbentuk dari mineral pada batubara asal melainkan dapat berasal dari bagian-bagian tabung uap yang terkelupas dalam boiler, pulverizer, dan dari tempat-tempat lain di sepanjang jalur yang dilewati batubara atau gas buang dan FA (Hower et al., 2017b).

Karakteristik FA yang dihasilkan dari PLTU di Pulau Jawa tersusun oleh glass $(50,7 \%)$, kuarsa $(19,7 \%)$, mulit $(12,6 \%)$, Mg-spinel $(12.2 \%)$, Fe-spinel $(9.5 \%)$, hematit $(9,8 \%)$, magnetit (14,4\%), K-felspar (4,9\%), dan UC berkisar 12,4\% (Besari, 2018). Sedangkan komposisi BA tersususn oleh glass $(39,6 \%)$, kuarsa $(16,2 \%)$, mulit $(8,2 \%)$, spinel $(15,3 \%)$, mineral oksida besi $(16,4 \%)$, dan UC berkisar 19,3\% (Besari, 2018).

Dai et al., (2010) melakukan studi terkait kelimpahan dan distribusi mineral dan unsur pada FABA hasil pembakaran batubara pada salah satu pembangkit listrik di Jungar di Mongolia. Berdasarkan studi tersebut diketahui bahwa komposisi mineral penyusun FABA dapat dibedakan berdasarkan sifat magnetiknya yaitu terdiri dari fraksi magnetik dan fraksi nonmagnetik. Kelompok mulit+korundum+ kuarsa (MCQ), dan glass dikelompokkan ke dalam fraksi non-magnetik. Kelimpahan 


\section{MAKALAH ILMIAH}

fraksi mineral penyusun FABA diperlihatkan pada Tabel 5.

CFA selain tersusun oleh material ekonomis seperti bahan magnetik, cenospheres, dan UC juga terdapat unsur jejak seperti V, Ga, $\mathrm{Ge}$, Se, Li, Mo, U, Au, Ag, Pt, dan REY (USEPA, 1999; Meawad et al., 2010). FABA dari PLTU di Pulau Jawa juga teridentifikasi
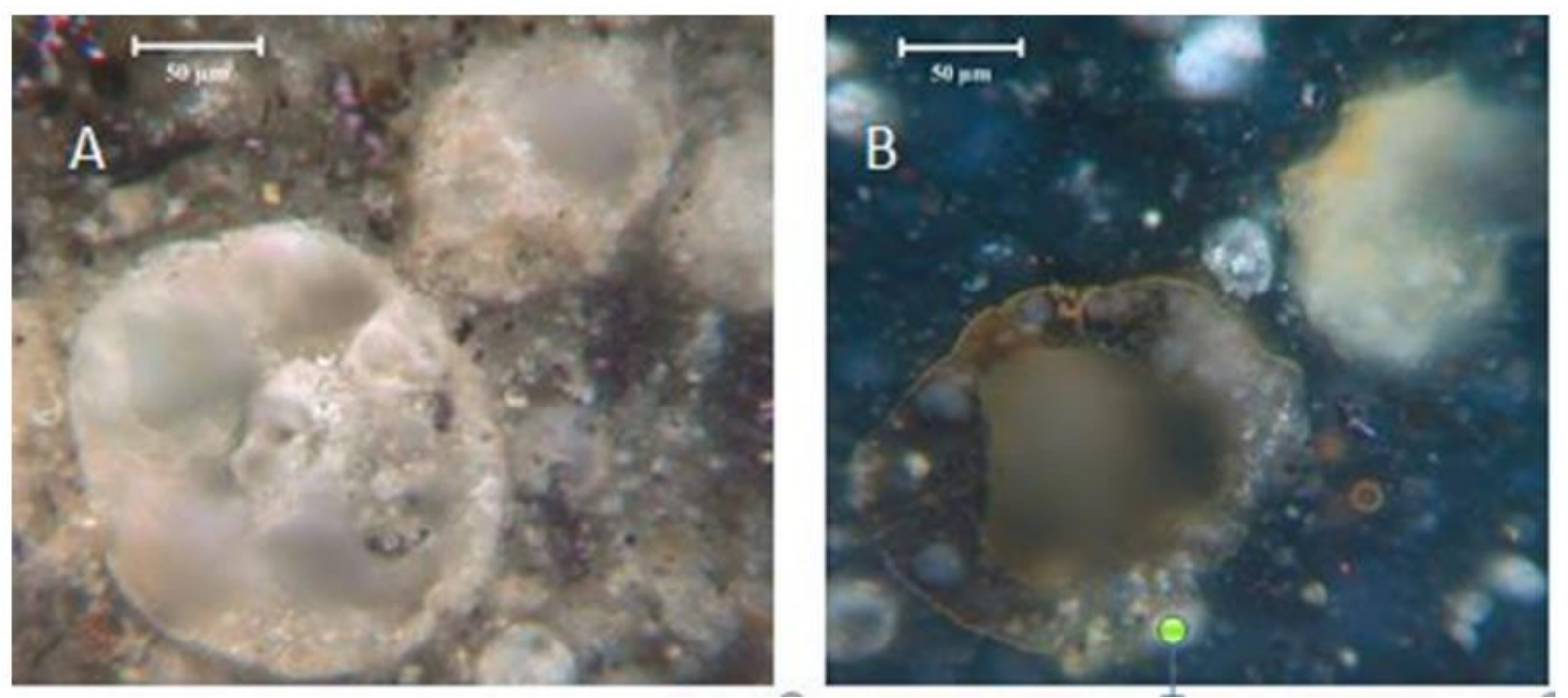

Gambar 5. (a).Cenospheres, (b). Pleiospheres Sumber: (Hower et al., 2017b)

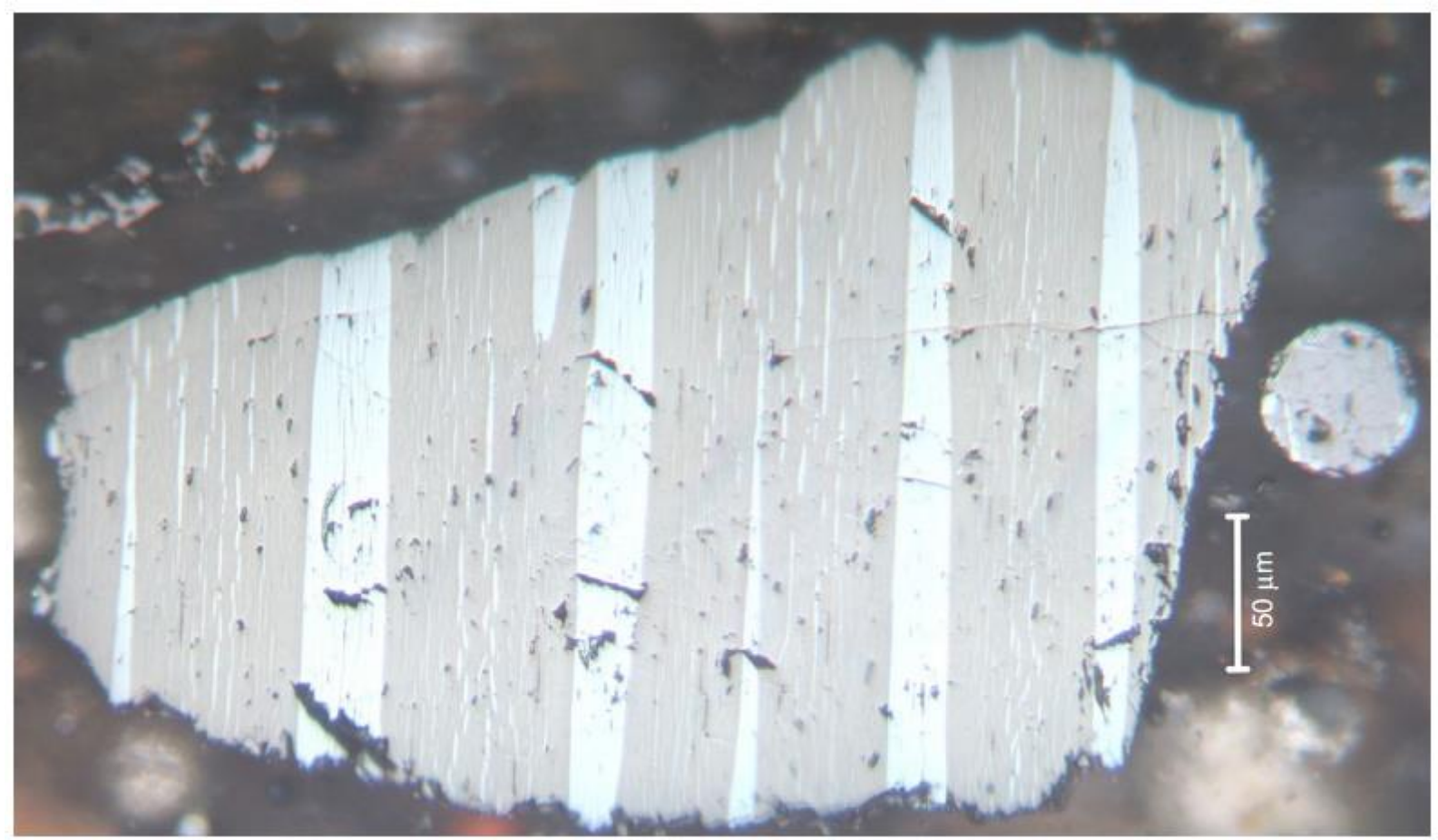

Gambar 6. Komponen non-bahan bakar berupa logam Sumber: (Hower et al., 2017b) 


\section{MAKALAH ILMIAH}

Tabel 5. Kelimpahan mineral penyusun FA dan BA Jungar Power Plant

\begin{tabular}{lcccccccc}
\hline \multirow{2}{*}{ Sampel } & \multicolumn{9}{c}{ Mineral } & \multirow{2}{*}{ Glass } & \multirow{2}{*}{ LOI } \\
\cline { 2 - 8 } & Mulit & Korundum & Kuarsa & Kalsit & K-felspar & & \\
\hline Fly ash (w) & 37,4 & 3,9 & 2,0 & 0,2 & 0,2 & 52,6 & 2,86 \\
\hline Fly ash (e) & 34,9 & 4,0 & 1,6 & 0,3 & 0,2 & 54,8 & 3,15 \\
\hline Bottom ash & 27,2 & 3,2 & 2,0 & 0,5 & 0,3 & 54,4 & 12,0 \\
\hline
\end{tabular}

Sumber: (Dai et al., 2010)

Tabel 6. Konsentrasi kelimpahan unsur jejak pada FA (mg/kg)

\begin{tabular}{ccc}
\hline Unsur & Median & Rentang \\
\hline $\mathrm{As}$ & 43,4 & $0,0003-391$ \\
$\mathrm{Ba}$ & 806,5 & $0,02-10,850$ \\
$\mathrm{Be}$ & 5 & $0,2-2105$ \\
$\mathrm{~B}$ & 311 & $2,98-2050$ \\
$\mathrm{Cd}$ & 3,4 & $0,01-79$ \\
$\mathrm{Cr}$ & 136 & $3,6-437$ \\
$\mathrm{Co}$ & 35,9 & $4,9-79$ \\
$\mathrm{Cu}$ & 112 & $0,2-655$ \\
$\mathrm{~F}$ & 29 & $0,04-320$ \\
$\mathrm{~Pb}$ & 56,8 & $0,02-273$ \\
$\mathrm{Mn}$ & 250 & $24,5-750$ \\
$\mathrm{Hg}$ & 0,1 & $0,013-49,5$ \\
$\mathrm{Ni}$ & 77,7 & $0.1-1270$ \\
$\mathrm{Se}$ & 7,7 & $0,0003-4,5$ \\
$\mathrm{Sb}$ & 4,6 & $0,2-205$ \\
$\mathrm{Ag}$ & 3,2 & $0,01-49,5$ \\
$\mathrm{Sr}$ & 775 & $30-3885$ \\
$\mathrm{Tl}$ & 9 & $0,15-85$ \\
$\mathrm{~V}$ & 252 & $43,5-5015$ \\
$\mathrm{Zn}$ & 148 & $0,8-2200$ \\
\hline Sumber: (USEPA, 1999; Meawad et al., 2010$)$
\end{tabular}
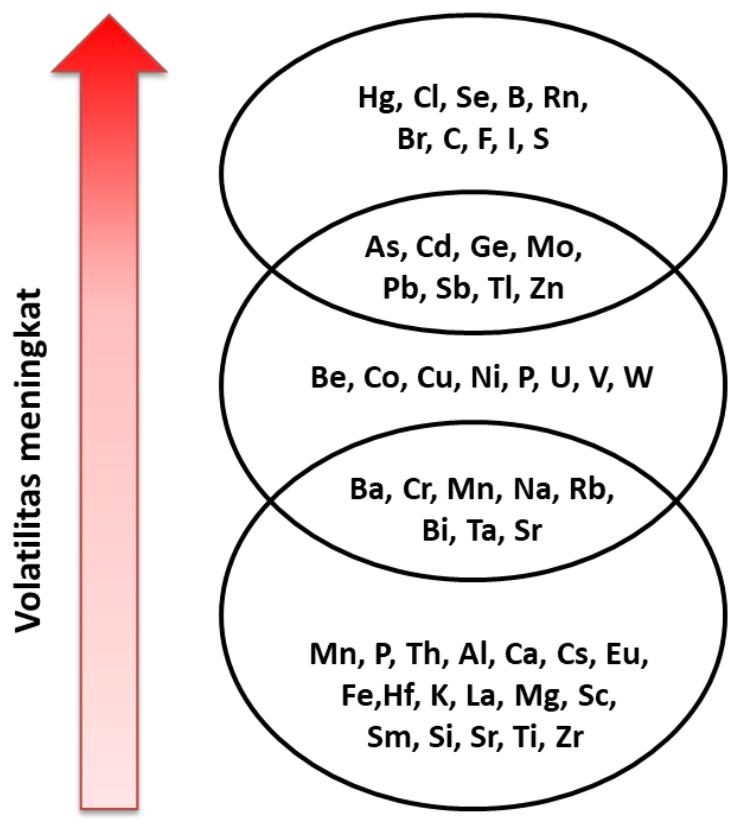

Grup 3 :

keluar bersama

gas buang

Grup 2 :

terikat dengan

Fly Ash

Grup 1 :

terikat dengan

Bottom Ash

Gambar 7. Distribusi unsur pada BA, FA, dan flue gas berdasarkan sifat volatilitas Sumber: (after Clarke, 1993; Meij, 1994) 


\section{POTENSI PEMANFAATAN FABA}

Pemanfaatan FA terbesar digunakan pada sektor pembuatan semen dan beton $(44,19 \%)$, pembuatan jalan dan tanggul $(15,25 \%)$, reklamasi daerah dataran rendah dan land filling $(12,49 \%)$, mine filling $(8,84 \%)$, pembuatan batu bata, balok, dan ubin $(7,61 \%)$, bidang pertanian $(2,47 \%)$, dan untuk bidang lainnya $(9,14 \%)$ (Loya and Rawani, 2014).

Kontras dengan produksi FABA di Indonesia yang terus meningkat secara signifikan dalam jumlah besar, secara umum pemanfaatan FABA yang dilakukan masih sangat terbatas sebagai material untuk penanganan masalah lingkungan di pertambangan (material timbunan, reklamasi, penanganan air asam tambang, roadbase jalan tambang), beton, paving block, dan campuran semen (Direktorat Jenderal Mineral dan Batubara , 2021).

Sifat fisik dan kimia FA memengaruhi potensi pemanfaatannya. Potensi pemanfaatan FA telah banyak diaplikasikan pada bidang geoteknik seperti stabilisasi tanah untuk jalan raya (Kolias et al., 2005); material pengurukan untuk penggalian, parit penambangan, serta dinding penahan (Wang and Wu, 2006); landfill liners atau penutup (Cokca and Yilmaz, 2004); dan sebagai bahan geopolimer (Chindaprasirt et al., 2011).

Untuk meningkatkan pemanfaatan FA, banyak teknik pemisahan telah dikembangkan, termasuk untuk memisahkan komponen bernilai ekonomis, seperti magnetit, aluminosilikat, unburned carbon, dan cenosphere. Cenospheres merupakan salah satu material berharga yang ditemukan FA karena memiliki sifat kuat tekan tinggi, ringan, daya serap air rendah, ketahanan kimia, dan ketahanan termal yang baik, menjadikannya cocok untuk berbagai aplikasi (Ranjbar and Kuenzel., 2017). Potensi pemanfaatan komponen penyusun FA lainnya antara lain sebagai berikut. (a). Sumber Rare Earth Element and Yttrium (REY)

FA yang apabila tidak digunakan hanya dianggap sebagai limbah, di sisi lain merupakan sumber beberapa unsur berharga (valuable elements), termasuk Rare earth elements and yttrium atau REY (Ketris and Yudovich, 2009; Blissett et al., 2014; Dai et al., 2012; Dai et al., 2014; Franus et al., 2015; Besari, 2018). Kepentingan komersial REY tidak hanya terlihat pada seberapa banyak penggunaannya, tetapi pada kenyataan bahwa unsur-unsur tersebut sangat penting dalam berbagai aplikasi termasuk teknologi utama untuk menghasilkan energi bersih dan berkelanjutan (Alonso et al., 2012; Du and Greadel, 2013; Seredin et al., 2013). Sumber daya REY tidak terlalu langka (deposit telah ditemukan di 34 negara, menurut Yang et al., (2013)), namun penambangan dan produksinya tidak murah dan dapat dikaitkan dengan dampak lingkungan yang signifikan (radioaktivitas unsur-unsur yang berasosiasi dengannya, seperti uranium dan thorium), memiliki subtitusi yang rendah, dan tingkat daur ulang yang rendah, sebagian besar ekonomi negara di dunia termasuk Uni Eropa (UE) sangat bergantung pada impor unsur tersebut (Massari and Rubeti, 2013).

REY juga disebut sebagai unsur tanah jarang (UTJ), rare earth metal (logam jarang), dan rare earth (tanah jarang). Menurut Humphries (2010), REY didefinisikan sebagai sekelompok unsur logam yang termasuk ke dalam golongan transisi atau golongan lanthanida, ditambah dengan yttrium ( $\mathrm{Y}$ ) dan scandium (Sc). Golongan lanthanida merupakan logam transisi dari Grup 11B pada tabel periodik. Golongan lanthanida terdiri atas 15 unsur, dimulai dari lanthanum (nomor atom 57) hingga lutetium (nomor atom 71), termasuk dua unsur tambahan yaitu $Y$ dan Sc.

REY digunakan pada berbagai bidang industri seperti pembuatan fuel cells, perangkat untuk green energy, baterai berkapasitas tinggi, dan magnet untuk 
pembangkit tenaga angin (Zhanheng, 2011; Hoenderdal et al., 2013; Franus et al., 2015). Selain itu selama tiga dekade terakhir terjadi peningkatan penggunaan REY dalam aplikasi pembuatan berbagai perangkat teknologi tinggi seperti memori komputer, compact disc, baterai isi ulang, konverter autokatalitik, super magnet, ponsel, perangkat LED, superkonduktor, bahan tambahan pembuatan kaca, bahan flouresen, phosphate binding agent, panel surya, dan agen pada magnetic resonance imaging (MRI) (Balaram, 2019).

Ketris and Yudowich (2009) menemukan bahwa coal fly ash (CFA) mengandung 445 ppm REY pada rata-rata global. Kelimpahan rata-rata REY pada abu batubara di dunia (404 ppm) dan di USA (517 ppm), bernilai tiga kali lebih besar dibandingkan dengan kelimpahan REY pada UCC. Seredin and Dai (2012) menemukan jika rata-rata kandungan REY dalam abu batubara memiliki konsentrasi yang sebanding dengan konsentrasi REY pada beberapa endapan bijih konvensional, sehingga limbah pembakaran batubara tersebut merupakan sumber potensial REY. Kelebihan lainnya adalah, pada CFA secara umum dapat ditemukan semua kelompok unsur REY sedangkan REY yang berasal dari endapan konvensional hanya memiliki beberapa variasi unsur tersebut di dalamnya.

Kriteria penilaian REY pada abu batubara sebagai bahan baku dipengaruhi oleh konsentrasi dan variasi individu REY (Seredin and Dai, 2012). Kriteria penilaian pertama adalah konsentrasi REY dalam bentuk oksida pada abu batubara (REO).

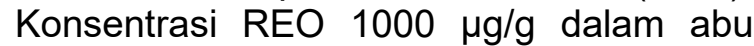
dianggap sebagai nilai batas untuk recovery REY yang menguntungkan. Kriteria kedua adalah komposisi individu REY dalam abu batubara. FA yang terkayakan oleh REY berdasarkan pada komposisi individual REY, tidak hanya mengacu pada kelimpahan total REY namun harus mempertimbangkan proporsi critical REY di dalamnya, serta rasio antara kelompok critical REY terhadap excessive REY yang dinyatakan sebagai koefisien outlook.
Eskenazy (1987) menemukan korelasi positif antara kadar abu batubara terhadap konsentrasi REY, yakni semakin tinggi kadar abu batubara maka konsentrasi REY semakin meningkat dan berlaku sebaliknya. REY dominan terikat pada mineral aluminasilikat dan terikat pada material organik penyusun batubara dengan konsentrasi yang sangat rendah $<10 \%$ dari konsentrasi total REY. Konsentrasi REY pada FA hasil pembakaran batubara bituminus dan lignit berkorelasi positif terhadap keberadaan aluminium dan silikon oksida (Franus et al., 2015). Querol et al. (1995) menemukan bahwa REY hanya terkonsentrasi pada material glass aluminosilikat. REY lebih terkayakan pada glass dibandingkan pada fraksi magnetik maupun MCQ. Glass cenderung mengalami pengayaan HREY, sedangkan pengayaan LREY cenderung terkayakan pada fraksi non-magnetik berupa MCQ (Dai et al., 2010). REY pada FA tidak hanya terikat di glass namun juga berasosiasi mineral karbonat dan fosfat (Querol et al., 2007).

Penelitian yang dilakukan oleh Blissett et al., (2014) menemukan bahwa 6 sampel abu hasil pembakaran batubara dari berbagai PLTU di Polandia dan UK teridentifikasi mengandung REY. Konsentrasi total REY pada seluruh sampel FA berkisar 246 ppm481 ppm dengan konsentrasi REO tidak lebih dari 600 ppm (hanya berkisar 297 ppm-579 ppm). Konsentrasi total critical REY berkisar 88 ppm-161 ppm, nilai koefisien outlook (Coutl) berkisar 0,86 0,96, dengan persentase critical REY sebesar 33,4\%-36,1\% (Blissett et al., 2014).

Kelompok unsur critical REY juga ditemukan pada FABA di Indonesia dengan kelimpahan berkisar dari 38\%-41\% dan nilai

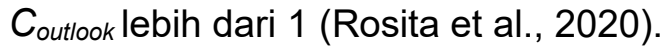

REY yang ditemukan pada FABA dari PLTU di Pulau Jawa memiliki kelimpahan total REY pada FA berkisar 123,14 s.d. 260,38 ppm (Besari, 2018). Konsentrasi total REO berkisar dari 148,61 s.d. 313,98 ppm dengan keterdapatan REY khususnya unsur $Y$ dominan terikat pada glass dan 
dalam konsentrasi lebih rendah terikat pada spinel (Besari, 2018). REY juga ditemukan terikat pada material organik penyusun batubara (Dai et al., 2008; Lin et al, 2017).

\section{(b). Cenosphere}

Pada komponen FABA terdapat fraksi material yang berbentuk bulat dan memiliki ruang kosong di bagian dalamnya. Partikel tersebut dinamakan sebagai cenosphere. Nama tersebut berasal dari bahasa Yunani yakni kenos (hollow) dan sphaira (sphere) (Torrey, 1978). Ukuran cenosphere bervariasi di antara rentang 20 hingga 300 $\mu \mathrm{m}$ (Ranjbar and Kuenzel, 2017). Sekitar $0,01-4,8 \%$ komponen fly ash adalah cenosphere dan di beberapa kasus, tercatat bahwa fraksi cenosphere berkisar antara 0,3-1,5\% (Sokol et al., 2000; Fomenko et al., 2013). Sebagian besar penyusun material ini adalah $\mathrm{SiO}_{2}$ dan $\mathrm{Al}_{2} \mathrm{O}_{3}$ berbedabeda tergantung dari sumber batubara yang dibakar (Ranjbar and Kuenzel, 2017; Danish and Mosaberpanah, 2020). Karena cenosphere sendiri bergantung pada sumber batubara yang digunakan, maka sifat dan karakteristiknya juga bermacammacam.

Cenosphere memiliki banyak kelebihan. Karena merupakan partikel berongga, terdapat fraksi yang berdensitas lebih rendah dari air. Umumnya densitas partikel ini berkisar antara 200 hingga $2.600 \mathrm{~kg} / \mathrm{m}^{3}$ (Acar and Atalay, 2016). Perbedaan tersebut dipengaruhi oleh ketebalan dinding atau cangkang cenosphere. Karena beratnya yang ringan dan memiliki kekerasan yang kuat, maka cenosphere dapat dimanfaatkan kebanyak pengaplikasian seperti material ringan, keramik ringan, filler, polimer, semen ringan, insulasi serta resistensi termal.

\section{(c). Geopolimer}

Geopolimer merupakan suatu polimer alam yang terbentuk akibat reaksi geopolimerisasi antara larutan silika dan aluminosilikat (Abdel-Gawwad and Abo ElEnein, 2016). Geopolimer juga dikenal dengan nama alkalibounded-ceramics, hidrokeramik, alkali-activated cements (Komnitsas and Zaharaki, 2007).
Geopolimer memiliki rumus empiris $\mathrm{Mn}\{-$ $\left.\left(\mathrm{SiO}_{2}\right) \mathrm{z}-\mathrm{AlO}_{2}\right\}$ n. $\mathrm{wH}_{2} \mathrm{O}$ dengan $\mathrm{M}$ kation alkali yang digunakan misalnya $(\mathrm{Na}+, \mathrm{K}+), \mathrm{n}$ derajat polikondensasi dan nilai $z$ bervariasi antara 1 sampai 3 . Nilai $z$ ini menunjukkan jenis oligomer aluminosilikat yang membentuk struktur amorf hingga semikristalin geopolimer seperti polysialate (-Si-O-Al-O-, PS), polysialate siloxo (-Si-OAl-O-Si-O-, PSS), ataupun polysialate disiloxo (-Si-O-Al-O-Si-O-Si-O-, PSDS) dan nilai z ditentukan oleh rasio Si/Al (Zhuang et al., 2016). Geopolimer yang terbentuk melalui proses geopolimerisasi memiliki sifat yang lebih baik dibandingkan dengan semen portland pada umumnya (AbdelGawwad and Abo El-Enein, 2016). Geopolimer memiliki nilai uji tekan yang tinggi, nilai susut yang rendah, ketahanan terhadap asam, nilai konduktivitas panas yang rendah, konsumsi energi yang rendah dalam pembuatan dan pemanfaatan di bidang konstruksi (Zhang et al., 2010). Geopolimer juga baik dalam hal imobilisasi logam berat dan stabil pada suhu tinggi (Yao et al., 2009).

FA banyak digunakan dalam industri pembuatan geopolimer karena kandungan aluminosilikat dan ukurannya yang lembut (Xie and Ozbakkaloglu, 2015). Struktur aluminosilikat yang ada pada FA tergantung pada jenis mineral yang terkandung dalam batubara. Mineral pada batubara dipengaruhi faktor geologi pada lingkungan sekitar deposit batubara. Mineral yang umum ditemukan pada batubara adalah mineral lempung seperti ilit $\left([\mathrm{OH}]_{4} \mathrm{~K}_{2}\left[\mathrm{Si}_{6} \mathrm{Al}_{2}\right] \mathrm{Al}_{4} \mathrm{O}_{20}\right)$ dan kaolinit $\left([\mathrm{OH}]_{8} \mathrm{Si}_{4} \mathrm{Al}_{4} \mathrm{O}_{10}\right)$, sulfida seperti pirit $\left(\mathrm{FeS}_{2}\right)$ dan markasit $\left(\mathrm{FeS}_{2}\right)$, karbonat seperti dolomit $\left(\mathrm{CaCO}_{3} \cdot \mathrm{MgCO}_{3}\right), \quad$ ankerit $\left(2 \mathrm{CaCO}_{3} \cdot \mathrm{MgCO}_{3} \cdot \mathrm{FeCO}_{3}\right)$, kalsit $\left(\mathrm{CaCO}_{3}\right)$ siderit $\left(\mathrm{FeCO}_{3}\right)$ dan kuarsa $\left(\mathrm{SiO}_{2}\right)$. Biasanya batubara mengandung $60-90 \%$ mineral lempung dan kuarsa sebanyak $1-20 \%$ dari total komponen anorganik yang ada pada batubara.

\section{(d). Unburned Carbon}

Fly ash (FA) juga mengandung unburned carbon (UC) dengan kelimpahan yang bervariasi hingga 17\% (Gray et al., 2002). 
Industri semen portland hanya menggunakan FA dengan nilai loss-onignition (LOI) kurang dari 6\%. UC direpresentasikan oleh LOI dan merupakan material yang tidak diharapkan dalam pembuatan beton karena dapat meningkatkan konduktivitas listrik beton; mengubah warna mortar dan beton (menjadi hitam); serta dibutuhkan penambahan baik air maupun zat aditif (Muralidharan et al., 2005). Menurut ASTM C618 dan EN 450-1, peningkatan LOI mengurangi kualitas FA karena kandungan karbon yang lebih tinggi, yang membatasi penerapannya pada beton karena aliran udara yang signifikan, memengaruhi daya tahan beton (Blisset and Rowson, 2012).

Penelitian yang dilakukan oleh Adelizar et al (2020) juga menunjukkan bahwa semakin tinggi persentase kelimpahan UC pada FABA PLTU Tanjung Jati Jepara mengakibatkan terjadinya penurunan nilai kuat tekan pada geopolimer yang dihasilkan. Analisis petrografi yang dilakukan oleh Besari (2018) pada sampel yang berasal dari PLTU Tanjung Jati menunjukkan kelimpahan UC pada sampel FA sebesar $14 \%$ dan pada sampel BA sebesar $18,7 \%$. Kelimpahan UC pada BA lebih tinggi jika dibandingkan pada FA. Nilai LOI pada FA sebesar $1,87 \%$ sedangkan pada BA mencapai 12.9\% (Adelizar et al., 2020).

UC pada CFA dapat digunakan sebagai bahan karbon aktif atau karbon hitam, bahan bakar tambahan, serta pembuatan grafit (Cabielles et al.,2009; Camea'n andb Garcia, 2011). Salah satu metode pemisahan UC yang telah banyak digunakan adalah metode elektrostatik (Gray et al., 2002; Soong et al., 2002). Metode lain yang menjanjikan memisahkan UC dari CFA adalah flotasi buih. Proses ini telah dikomersialkan di AS dengan kadar karbon yang dapat diekstraksi mencapai 70\% (Baltrus et al.,2001).

\section{KESIMPULAN}

Karakteristik komponen penyusun FABA yang dihasilkan dari pembakaran batubara di PLTU secara umum tersusun oleh komponen organik dan anorganik, senyawa oksida utama, unsur jejak, maupun material dan unsur berharga. FABA berdasarkan karakteristik komponen penyusunnya dapat dimanfaatkan sebagai bahan baku pembuatan geopolimer, maupun sebagai sumber material berharga seperti cenosphere dan unburned carbon, selain itu juga dapat dilakukan ekstraksi unsur-unsur berharga yang bernilai ekonomi tinggi yaitu antara lain REY atau unsur tanah jarang.

\section{DAFTAR PUSTAKA}

Abbott, M.F. and Austin, L.G., 1985. Studies on slag deposit formation in pulverized-coal combustors: 6 . sticking behaviour of slag drops from three Pennsylvania steam coals. Fuel, 64(6), pp.832-838.

Abdel-Gawwad, H.A. and Abo-El-Enein, S.A., 2016. A novel method to produce dry geopolymer cement powder. HBRC journal, 12(1), pp.1324.

Acar, I. and Atalay, M.U., 2016. Recovery potentials of cenospheres from bituminous coal fly ashes. Fuel, 180, pp.97-105.

Adelizar, A.S., Olvianas, M., Adythia, D.M., Syafiyurrahman, M.F., Pratama, I.G.A.A.N., Astuti, W. and Petrus, H.T.B.M., 2020. Fly ..ash and bottom ash utilization as geopolymer: Correlation on compressive strength and degree of polymerization observed using FTIR. MS\&E, 742(1), p.012042.

Ahmaruzzaman, M., 2010. A review on the utilization of fly ash. Progress in energy and combustion science, 36(3), pp.327-363. 
Alonso, E., Sherman, A.M., Wallington, T.J., Everson, M.P., Field, F.R., Roth, R. and Kirchain, R.E., 2012. Evaluating rare earth element availability: A case with revolutionary demand from clean technologies. Environmental science \& technology, 46(6), pp.3406-3414.

Balaram, V., 2019. Rare earth elements: A review of applications, occurrence, exploration, analysis, recycling, and environmental impact. Geoscience Frontiers, 10(4), pp.1285-1303.

Besari, D.A.A., 2018. Komponen Penyusun dan Model Keterdapatan Rare Earth Elements and Yttrium (REY) pada Fly Ash dan Bottom Ash (Bachelor thesis, Universitas Gadjah Mada).

Bhatt, A., Priyadarshini, S., Mohanakrishnan, A.A., Abri, A., Sattler, M. and Techapaphawit, S., 2019. Physical, chemical, and geotechnical properties of coal fly ash: a global review. Case Studies in Construction Materials, 11, p.e00263.

Blissett, R.S. and Rowson, N.A., 2012. A review of the multi-component utilisation of coal fly ash. Fuel, 97, pp.1-23.

Blissett, R.S., Smalley, N. and Rowson, N.A., 2014. An investigation into six coal fly ashes from the United Kingdom and Poland to evaluate rare earth element content. Fuel, 119, pp.236-239.

Cabielles, M., Rouzaud, J.N. and Garcia, A.B., $2009 . \quad$ High-resolution transmission electron microscopy studies of graphite materials prepared by high-temperature treatment of unburned carbon concentrates from combustion fly ashes. Energy \& fuels, 23(2), pp.942-950.

Cameán, I. and Garcia, A.B., 2011. Graphite materials prepared by HTT of unburned carbon from coal combustion fly ashes: Performance as anodes in lithium-ion batteries. Journal of Power Sources, 196(10), pp.4816-4820.

Chiang, P.C. and Pan, S.Y., 2017. Fly Ash, Bottom Ash, and Dust. In Carbon Dioxide Mineralization and Utilization (pp. 253-264). Springer, Singapore.
Chindaprasirt, P., Chareerat, T., Hatanaka, S. and Cao, T., 2011. High-strength geopolymer using fine high-calcium fly ash. Journal of Materials in Civil Engineering, 23(3), pp.264-270.

Clarke, L.B., 1993. The fate of trace elements during coal combustion and gasification: an overview. Fuel, 72(6), pp.731-736.

Cokca, E. and Yilmaz, Z., 2004. Use of rubber and bentonite added fly ash as a liner material. Waste management, 24(2), pp.153-164.

Dai, S., Ren, D., Zhou, Y., Chou, C.L., Wang, X., Zhao, L. and Zhu, X., 2008. Mineralogy and geochemistry of a superhigh-organic-sulfur coal, Yanshan Coalfield, Yunnan, China: evidence for a volcanic ash component and influence by submarine exhalation. Chemical Geology, 255(1-2), pp.182-194.

Dai, S., Zhao, L., Hower, J.C., Johnston, M.N., Song, W., Wang, P. and Zhang, S., 2014. Petrology, mineralogy, and chemistry of size-fractioned fly ash from the Jungar power plant, Inner Mongolia, China, with emphasis on the distribution of rare earth elements. Energy \& fuels, 28(2), pp.1502-1514.

Dai, S., Zhao, L., Peng, S., Chou, C.L., Wang, X., Zhang, Y., Li, D. and Sun, Y., 2010. Abundances and distribution of minerals and elements in highalumina coal fly ash from the Jungar Power Plant, Inner Mongolia, China. International Journal of Coal Geology, 81(4), pp.320-332.

Danish, A. and Mosaberpanah, M.A., 2020. Formation mechanism and applications of cenospheres: a review. Journal of Materials Science, pp.1-19.

Direktorat Jenderal Mineral dan Batubara, 2021. Fly ash dan bottom ash (FABA) di Indonesia (press release). Jakarta : Direktorat Jenderal Mineral dan Batubara Kementerian Energi dan Sumberdaya Mineral.

Direktorat Jenderal Mineral dan Batubara, 2019. Laporan Kinerja Tahun 2019. Jakarta : Direktorat Jenderal Mineral dan Batubara Kementerian Energi dan Sumber daya Mineral. 
https://esdm.go.id/assets/media/cont ent/content-laporan-kinerja-ditjenminerba2019.pdf

Du, X. and Graedel, T.E., 2013. Uncovering the end uses of the rare earth elements. Science of the Total Environment, 461, pp.781-784.

Eskenazy, G.M., 1987. Rare earth elements in a sampled coal from the Pirin deposit, Bulgaria. International Journal of Coal Geology, 7(3), pp.301314.

Fomenko, E.V., Anshits, N.N., Solovyov, L.A., Mikhaylova, O.A. and Anshits, A.G., 2013. Composition and morphology of fly ash cenospheres produced from the combustion of Kuznetsk coal. Energy \& fuels, 27(9), pp.5440-5448.

Franus, W., Wiatros-Motyka, M.M. and Wdowin, M., 2015. Coal fly ash as a resource for rare earth elements. Environmental Science and Pollution Research, 22(12), pp.9464-9474.

Goodarzi, F., 2006. Characteristics and composition of fly ash from Canadian coal-fired power plants. Fuel, 85(1011), pp.1418-1427.

Gray, M.L., Champagne, K.J., Soong, Y., Killmeyer, R.P., Maroto-Valer, M.M., Andrésen, J.M., Ciocco, M.V. and Zandhuis, P.H., 2002. Physical cleaning of high carbon fly ash. Fuel processing technology, 76(1), pp.1121.

Hoenderdaal, S., Espinoza, L.T., Marscheider-Weidemann, F. and Graus, W., 2013. Can a dysprosium shortage threaten green energy technologies?. Energy, 49, pp.344355.

Hower, J.C., 2012. Petrographic examination of coal-combustion fly ash. International Journal of Coal Geology, 92, pp.90-97.

Hower, J.C., Henke, K.R., Dai, S., Ward, C.R., French, D., Liu, S. and Graham, U.M., 2017a. Generation and nature of coal fly ash and bottom ash. In Coal Combustion Products (CCP's) (pp. 21-65). Woodhead Publishing.
Hower, J.C., Groppo, J.G., Graham, U.M., Ward, C.R., Kostova, I.J., MarotoValer, M.M. and Dai, S., 2017b. Coalderived unburned carbons in fly ash: $A$ review. International Journal of Coal Geology, 179, pp.11-27.

Ketris, M.P. and Yudovich, Y.E., 2009. Estimations of Clarkes for Carbonaceous biolithes: World averages for trace element contents in black shales and coals. International Journal of Coal Geology, 78(2), pp.135-148.

Kolias, S., Kasselouri-Rigopoulou, V. and Karahalios, A., 2005. Stabilisation of clayey soils with high calcium fly ash and cement. Cement and Concrete Composites, 27(2), pp.301-313.

Komnitsas, K. and Zaharaki, D., 2007. Geopolymerisation: A review and prospects for the minerals industry. Minerals engineering, 20(14), pp.1261-1277.

Kutchko, B.G. and Kim, A.G., 2006. Fly ash characterization by SEM-EDS. Fuel, 85(17-18), pp.2537-2544.

Lin, R., Bank, T.L., Roth, E.A., Granite, E.J. and Soong, Y., 2017. Organic and inorganic associations of rare earth elements in central Appalachian coal. International Journal of Coal Geology, 179, pp.295-301.

Loya, M.I.M. and Rawani, A.M., 2014. A review: promising applications for utilization of fly ash. Int. J. Adv. Technol. Eng. Sci, 2, pp.143-149.

Massari, S. and Ruberti, M., 2013. Rare earth elements as critical raw materials: Focus on international markets and future strategies. Resources Policy, 38(1), pp.36-43.

Meawad, A.S., Bojinova, D.Y. and Pelovski, Y.G., 2010. An overview of metals recovery from thermal power plant solid wastes. Waste Management, 30(12), pp.2548-2559.

Meij, R., 1994. Trace element behavior in coal-fired power plants. Fuel processing technology, 39(1-3), pp.199-217. 
Mraw, S.C., De Neufville, J.P., Freund, H., Baset, Z., Gorbaty, M.L. and Wright, F.J., 1983. The science of mineral matter in coal. In Coal science (pp. 163). Academic Press.

Mukherjee, A.B., Zevenhoven, R., Bhattacharya, P., Sajwan, K.S. and Kikuchi, R., 2008. Mercury flow via coal and coal utilization by-products: a global perspective. Resources, Conservation and Recycling, 52(4), pp.571-591.

Ngu, L.N., Wu, H. and Zhang, D.K., 2007. Characterization of ash cenospheres in fly ash from Australian power stations. Energy \& Fuels, 21(6), pp.3437-3445.

Pandian, N.S., 2013. Fly ash characterization with reference to geotechnical applications. Journal of the Indian Institute of Science, 84(6), p.189.

Reddy, C.S., Mohanty, S. and Shai, R., 2018. Physical, chemical and geotechnical characterization of fly ash, bottom ash and municipal solid waste from Telangana State in India. International Journal of GeoEngineering, 9(23).

Querol, X., Fernández-Turiel, J. and LópezSoler, A., 1995. Trace elements in coal and their behaviour during combustion in a large power station. Fuel, 74(3), pp.331-343.

Ram, L.C. and Masto, R.E., 2014. Fly ash for soil amelioration: a review on the influence of ash blending with inorganic and organic amendments. Earth-Science Reviews, 128, pp.5274.

Ranjbar, N. and Kuenzel, C., 2017. Cenospheres: A review. Fuel, 207, pp.1-12.

Rosita, W., Besari, D.A.A., Bendiyasa, I.M., Perdana, I., Anggara, F., and Petrus, H.T.B.M., 2020. Potency of rare earth elements and yttrium in Indonesian coal ash. Key Engineering Materials, 849, pp.102-107.
Sahoo, P.K., Kim, K., Powell, M.A. and Equeenuddin, S.M., 2016. Recovery of metals and other beneficial products from coal fly ash: A sustainable approach for fly ash management. International Journal of Coal Science \& Technology, 3(3), pp.267-283.

Seredin, V.V. and Dai, S., 2012. Coal deposits as potential alternative sources for lanthanides and yttrium. International Journal of Coal Geology, 94, pp.67-93.

Seredin, V.V., Dai, S., Sun, Y. and Chekryzhov, I.Y., 2013. Coal deposits as promising sources of rare metals for alternative power and energyefficient technologies. Applied Geochemistry, 31, pp.1-11.

Sokol, E.V., Maksimova, N.V., Volkova, N.I., Nigmatulina, E.N. and Frenkel, A.E., 2000. Hollow silicate microspheres from fly ashes of the Chelyabinsk brown coals (South Urals, Russia). Fuel Processing Technology, 67(1), pp.35-52.

Sommerville, R., Blissett, R., Rowson, N. and Blackburn, S., 2013. Producing a synthetic zeolite from improved fly ash residue. International Journal of Mineral Processing, 124, pp.20-25.

Srinivasachar, S., Helble, J.J. and Boni, A.A., 1990. Mineral behavior during coal combustion 1. Pyrite transformations. Progress in Energy and Combustion Science, 16(4), pp.281-292.

Torrey, S., 1978. Coal ash utilization: Fly ash, bottom ash and slag. Noyes Data Corporation (Pollution technology review).

Vassilev, S.V. and Vassileva, C.G., 2007. A new approach for the classification of coal fly ashes based on their origin, composition, properties, and behaviour. Fuel, 86(10-11), pp.14901512.

Wang, S. and Wu, H., 2006. Environmentalbenign utilisation of fly ash as low-cost adsorbents. Journal of hazardous materials, 136(3), pp.482-501. 


\section{MAKALAH ILMIAH}

Xie, T. and Ozbakkaloglu, T., 2015. Behavior of low-calcium fly and bottom ash-based geopolymer concrete cured at ambient temperature. Ceramics International, 41(4), pp.5945-5958.

Yang, X.J., Lin, A., Li, X.L., Wu, Y., Zhou, W. and Chen, Z., 2013. China's ionadsorption rare earth resources, mining consequences and preservation. Environmental Development, 8, pp.131-136.

Yao, Z.T., Ji, X.S., Sarker, P.K., Tang, J.H., Ge, L.Q., Xia, M.S. and Xi, Y.Q., 2015. A comprehensive review on the applications of coal fly ash. EarthScience Reviews, 141, pp.105-121.

Yao, X., Zhang, Z., Zhu, H. and Chen, Y., 2009. Geopolymerization process of alkali-metakaolinite characterized by isothermal calorimetry. Thermochimica Acta, 493(1-2), pp.4954.
Zhang, Y.J., Wang, Y.C. and Li, S., 2010. Mechanical performance and hydration mechanism of geopolymer composite reinforced by resin. Materials Science and Engineering: $A$, 527(24-25), pp.6574-6580.

Zhanheng, C., 2011. Global rare earth resources and scenarios of future rare earth industry. Journal of rare earths, 29(1), pp.1-6.

Zhuang, X.Y., Chen, L., Komarneni, S., Zhou, C.H., Tong, D.S., Yang, H.M., $\mathrm{Yu}$, W.H. and Wang, H., 2016. Fly ash-based geopolymer: clean production, properties and applications. Journal of Cleaner Production, 125, pp.253-267.

\begin{tabular}{ll|}
\hline Diterima & $:$ 19 Maret 2021 \\
Direvisi & $: 29$ Maret 2021 \\
Disetujui & $: 31$ Mei 2021
\end{tabular}

